\title{
Diagnostic challenges in patients with suspected Lyme neuroborreliosis
}

\author{
I. M. Poiasnyk 10 * \\ Ivano-Frankivsk National Medical University, Ukraine
}

Lyme neuroborreliosis is a tick-borne spirochetal infection, which may affect the peripheral or central nervous system at the early or late stages of the disease.

The purpose of the work is to analyze modern scientific literature on the issues of clinical manifestations, diagnostics of early and late Lyme neuroborreliosis.

Analysis of the scientific literature related to the diagnosis of Lyme neuroborreliosis was carried out. According to the authors of the researches, it was found that clinical presentation varies with disease stage, and Lyme neuroborreliosis is reported in up to $25 \%$ of patients with Lyme disease. The clinical manifestations of this not uncommon disorder nowadays depend on the neurological structures which are primarily involved. The full clinical picture of Lyme neuroborreliosis may mimic other diseases, so atypical symptoms can result in diagnostic delay or misdiagnosis.

Conclusions. The incidence of Lyme neuroborreliosis seems to be much higher than previously assumed. Cerebrospinal fluid examination (detection of Borrelia burgdorferi lgM and lgG specific antibodies) is essential for the diagnosis of early and late Lyme neuroborreliosis, as successful treatment of early Lyme neuroborreliosis can prevent the expensive and devastating consequences of late Lyme neuroborreliosis.

\section{Складнощі діагностики в пацієнтів із припущенням про інфікування нейробореліозом}

\section{І. М. Поясник}

Нейробореліоз - інфекція, що викликана спірохетами, може впливати на периферичну або центральну нервову систему на ранніх або пізніх стадіях захворювання.

Мета роботи - аналіз сучасної наукової літератури щодо клінічних проявів, діагностики раннього й пізнього нейробореліозу. Здійснили аналіз наукової літератури з питань діагностики нейробореліозу. За результатами досліджень багатьох авторів, клінічна картина змінюється залежно від стадії захворювання, і нейробореліоз диагностують у 25 \% пацієнтів із хворобою Лайма. Клінічні прояви цього нерідкісного захворювання залежать від ураження неврологічних структур, що залучаються першими. Клінічна картина нейробореліозу може імітувати інші захворювання, тому атипові симптоми можуть спричинити затримку чи неправильну діагностику.

Висновки. Захворюваність на нейробореліоз, імовірно, набагато вища, ніж передбачали раніше. Обстеження спинномозкової рідини (виявлення специфрічних антитіл IgM та IgG до Borrelia burgdorferi) має важливе значення для діагностики раннього та пізнього нейробореліозу, оскільки успішне лікування раннього нейробореліозу може запобігти тяжким наслідкам пізнього нейробореліозу.

\section{Сложности диагностики у пациентов с подозрением на нейроборрелиоз}

\section{И. М. Пояснык}

Нейроборрелиоз - инфекция, вызванная спирохетами, может поражать периферическую или центральную нервную систему на ранних или поздних стадиях заболевания.

Цель работы - анализ современной научной литературы по вопросам клинических проявлений, диагностики раннего и позднего нейроборрелиоза Лайма.

Проведен анализ научной литературы, связанной с диагностикой нейроборрелиоза. Согласно исследованиям авторов, клиническая картина варьируется в зависимости от стадии заболевания, и нейроборрелиоз регистрируют у $25 \%$ пациентов с болезнью Лайма. Клинические проявления этого нередкого расстройства зависят от поражения неврологических структур, которые вовлекаются в первую очередь. Полная клиническая картина нейроборрелиоза может имитировать другие заболевания, поэтому нетипичные симптомы могут привести к задержке или неправильной диагностике.

Выводы. Заболеваемость нейроборрелиозом, по-видимому, намного выше, чем предполагалось ранее. Исследование спинномозговой жидкости (обнаружение специфических антител IgM и lgG к Borrelia burgdorferi) имеет важное значение для диагностики раннего и позднего нейроборрелиоза, поскольку успешное лечение раннего нейроборрелиоза может предотвратить тяжелые последствия позднего нейроборрелиоза.

Lyme borreliosis (LB) mainly exists between the 40th and 60th parallels of the northern hemisphere in line with the presence of its vectors. Although direct evidence is lacking, the increase in LB is very likely partially caused by the increase and spread of Ixodes ricinus populations
Key words:

Lyme neuroborreliosis, early diagnosis, late diagnosis.

Zaporozhye medical journal 2020; 22 (2), 275-280 *E-mail: sof.3425@gmail.com

Ключові слова: нейробореліоз, рання діагностика, пізня Аіагностика.

Запорізький медичний журнал. 2020. T. 22, № 2(119) C. $275-280$

Ключевые слова: нейроборрелиоз, ранняя Аиагностика, позАняя Аиагностика.

\section{Запорожский} медицинский журнал 2020. T. 22, № 2(119). C. $275-280$
[1]. Tick suitable areas in Europe are expanding, particularly due to reforestation and other actions to restore and protect nature [2-5]. The current policy of some European countries is to create more green spaces in (sub)urban areas to improve human health and well-being, and to 
mitigate the health risks such as heat wave, air pollution and flooding (Committee on Climate Change, 2014). It is important to realize, however, that these spaces may also enhance opportunities for contact between humans and I. ricinus, posing risks for acquiring tick-borne diseases [6-8].

Lyme neuroborreliosis (LNB) is a clinical manifestation of $L B$, which affects the central nervous system (CNS) and peripheral nervous system (PNS) caused by spirochetes of the genus Borrelia burgdorferi $(\mathrm{Bb})$ sensu lato complex and spread by the bite of ticks of the genus /xodes [9]. LNB is a controversial clinical conundrum: it can be cured with prompt and adequate care, but delayed diagnosis and treatment contribute significantly to the high mortality and morbidity rates associated with the disease. Diagnosis is challenging due to nonspecific presentation and the time-consuming cultures required for confirmation.

\section{Aim}

The aim is to analyze modern scientific literature on the issues of clinical manifestations, diagnostics of early and late Lyme neuroborreliosis.

Skin manifestations. In a substantial proportion of patients with LNB is preceded by skin manifestations. It is therefore vital to obtain a detailed history in order to establish probable exposure to Ixodes ticks in an endemic area at an appropriate time of year and to obtain appropriate and definitive laboratory confirmation. This is a point that should be strongly emphasized to avoid misdiagnosis and further complications [10].

Localised cutaneous early-stage infection. The skin around the infectious tick bite can become infected anywhere from 3 to 30 days after the tick bite occurs [1]. Erythema migrans (EM) lesion starts from a macule or papule and expands over a period of days to weeks to form a red or bluish-red patch, with or without central clearing. The advancing edge is typically distinct and is often intensely coloured but not markedly elevated [11]. If the diameter of the erythema is more than $5 \mathrm{~cm}$, a diagnosis of erythema migrans can be made. The EM may be accompanied by fatigue, fever, headache, mild stiff neck, arthralgia and myalgia, but such symptoms are not indicative of LB if they occur in the absence of EM [1,12-14]. The diagnosis of EM is clinical.

Borrelial lymphocytoma (lymphadenosis benigna cutis, $\mathrm{BL}$ ) is rare. It is a painless bluish-red nodule or plaque, usually found on the ear lobe, ear helix, nipple or scrotum and occurs more frequently in children (especially on the ear) than in adults [11]. Patients with BL are usually seropositive at the time of presentation. A small proportion of patients with initially negative results usually seroconverts within a short period [15]. Histology is required in case of diagnostic uncertainty to exclude cutaneous lymphoma or other malignancies. BL has a typical histological appearance with an intense polyclonal B-lymphocytic infiltrate $[1,16]$.

Cutaneous late manifestations. Acrodermatitis chronica atrophicans (ACA) is almost exclusively seen in adults, predominantly women, though ACA-like lesions in children have been reported occasionally [17]. The disease can manifest itself in various organs after varying periods of time, from months to years depending on the individual [1]. It is a long-lasting, usually progressive manifestation of $L B$, characterized by red or bluish-red lesions, usually on the extensor surfaces of the extremities. Initially there is a bluish-red discolouration, often with doughy swelling. Skin atrophy becomes more and more prominent later on. Fibroid nodules may develop over bony prominences and sclerodermic changes may develop in atrophic skin areas $[1,11]$. The lesion has a typical histological appearance with telangiectases, a patchy or band-like lymphocytic and plasma cell infiltrate, and a greater or lesser degree of skin atrophy, which, however, is not diagnostic per se [18]. Involvement of peripheral nerves is not uncommon, locally at the site of skin lesion, usually as large-fibre axonal polyneuropathy with predominantly mild sensory symptoms $[19,20]$. Serum IgG antibodies to B. burgdorferi are present in high concentrations [11].

Clinical features. Nerve structures are affected by spirochetes both in acute and late phase of the disease. A distinction between early (acute) and late (chronic) phase of LNB can be made. The acute phase occurs in less than 6 months after contacting an infected arthropod and chronic LNB sets in more than 6 months or even years later after the initial infection $[21,22]$. According to Steere, the frequency of neurological manifestations in case of LB is about $15-25 \%$ [22].

Early Lyme neuroborreliosis. Neurological symptoms usually occur 1-12 (mostly 4-6) weeks after the tick bite, and mainly from July to December. Only $40-50 \%$ of the patients can recall a tick bite, and $20-30 \%$ report a local skin infection (erythema migrans) (stage I). More than $95 \%$ can be classified as early LNB (stage II), identified as signs and symptoms lasting for $<6$ months [23].

Central nervous system disorders. Acute borrelia meningitis is the most common manifestation of early LNB. It often occurs in the secondary stage of the disease in approximately $20 \%$ of untreated patients, being more common in children and adolescents; $16 \%$ of all lymphocytic meningitis cases are represented by it. Acute borrelia meningitis is often associated with cranial neuritis (the most affected nerve is the facial nerve) and radiculoneuritis, resulting in Bannwarth syndrome or meningoradiculitis which is a typical manifestation of LNB $[24,25]$.

Symptoms of meningitis are fever $\left(38^{\circ} \mathrm{C}\right)$, pain (myalgia, arthralgia, cutaneous hyperesthesia), intracranial hypertension syndrome, meningeal irritation (neck stiffness, positive Kerning sign). These symptoms are often nonspecific, of mild intensity; they may occur as isolated or accompanied by cranial radiculoneuropathy, nervous system manifestations (Bannwarth syndrome) as well as be associated with signs of brain injury (confusion, ataxic hemiparesis with cerebellar dysarthria, symptoms of parkinsonism, etc) [26,27].

Lyme encephalomyelitis is a uni- or multifocal inflammatory manifestation of the CNS. CNS damage may be isolated, but in most cases may be associated with the meningeal and peripheral one, with clinical manifestations of acute meningoencephalitis, acute meningoencephalomyelitis, and acute polyradiculoneuritis encephalomyelitis. Cerebromedullary manifestations are generally single phase, slowly progressive and the cerebral white matter is affected [28]. 
Manifestations of Lyme encephalomyelitis are usually described with low intensity and mild severity such as: isolated Babinski sign, transient disorders of the sphincters, sleep and memory disorders and behavioural changes. In severe cases, brain damage can produce seizures, mental confusion, agitation, hallucinatory delirium, chorea, hemiparesis, cerebellar ataxia, choreoathetosis, dystonia [29].

Sometimes radicular inflammation intensifies, which can cause mild or moderate symptoms of myelitis, in most cases with a clinical picture of encephalomyelitis or pure myelitis, which can simulate multiple sclerosis or spinal cord compression $[30,31]$.

Peripheral nervous system disorders. Disorders of the cranial nerve. Frequency of cranial nerve injuries is estimated to be $30-40 \%$ of the cases. The most common condition is uni- or bilateral facial nerve palsy, which often presents favorable evolution, recovery can be accomplished even without therapy in 1-2 months. Recovery takes several months rarely and in $10 \%$ of the cases it may be incomplete. Cranial nerve disorder in case of LNB is more common at the second stage of the disease [32]. Other cranial nerves can also be involved, particularly the oculomotor and the trigeminal nerve, disorders of the VIII, IX, XII pairs of cranial nerves are also possible [22].

Radiculoneuritis occurs in approximately $1 / 3$ of patients suffering from neurological disorders, accompanied by pleocytosis in cerebrospinal fluid (CSF) (85\% of cases) and cranial neuropathy (70 \% of cases). Symptomatology comprises radicular pain, paresthesia and/or hyperaesthesia, which usually appear on average 30 days after the initial infection; typical regions of appearance are the lower and upper extremities [33]. Pain syndrome can start as acute or subacute in character, usually at the level of the body or proximal part of the limbs and can reach full intensity within hours to several days. Once started, pain can persist for weeks ( 6 weeks to $3-6$ months) before spontaneous remission. Usually the pain syndrome has moderate intensity during the day, but it becomes exacerbated during the night; pain generally remains localized at the level of a dermatome or adjacent area, rarely becoming diffuse or pluriradicular. Although not specific and often responsible for insomnia, the nocturnal appearance of pain syndrome has major clinical significance [31].

Pain caused by radiculoneuritis is the first and in 20$25 \%$ of patients the only one neurologic symptom of early LNB [31]. Physical examination may be normal or reveal hypoesthesia, muscle weakness and/or abolition of reflexes in the painful area or diffuse dysfunction. Radicular lesions may be accompanied or followed by unsteady paralytic peripheral or cranial nerve injury after a symptom-free interval of several weeks [34]. Etiological treatment, in comparison with the ineffectiveness of symptomatic therapy, has a beneficial effect on painful manifestations of the radicles. This favorable evolution of the post-antibacterial therapy, which generally occurs within 72 hours after onset, is an excellent argument in favor of the diagnosis of radiculoneuritis associated with LNB [33,35].

Peripheral motor nerve damage. Motor nerves damage, which is less common ( $20 \%$ of cases) than sensory nerves damage, is responsible for asymmetric paralysis. It is more often localized proximal than distal in some muscle groups, which are responsible for amyotrophy. Physical examination reveals diminished or abolished deep tendon reflexes in the area where paralysis or sometimes diffuse muscle damage occurs. The evolution of the disease can be prolonged and sequelae may appear. This type of paralysis often regresses in six to eight weeks $[31,36]$.

Diagnosis. Almost all guidelines recommend CSF examination (cell count and protein) and search for intrathecal antibody production for the diagnosis of early LNB. Intrathecal production is the diagnostic gold standard, but has limitations such as low sensitivity at the very early stage of the disease and its persistence for years after eradication of the infection [35].

A pleocytosis in CSF is most frequently observed, with 10 to 1000 leukocytes $/ \mathrm{mm}^{3}$, mainly lymphocytes and elevated protein [37]. According to the European Federation of Neurological Societies (EFNS) guidelines, a normal cell count or absence of leukocytes in European LNB is rare but possible - especially at the very early stage - in immunosuppressed patients or during LNB caused by $B$. afzelii [38].

The European Society of Clinical Microbiology and Infectious Diseases Study Group on Lyme Borreliosis (ESGBOR) guidelines specify that the diagnostic sensitivity of the intrathecal synthesis is about $80 \%$ in patients with shorter duration ( $<6-8$ weeks) of clinical disease and nearly $100 \%$ with longer disease duration. The characteristic spectrum of bands, particularly in the lgG immunoblot, also provides evidence to divide the immune response into an early and a late stage. Antibodies against early phase antigens (e.g., VIsE, OspC, p41) are typically compatible with an early presentation (e.g., facial palsy) or a brief latent infection, whereas late phase antigens (e.g., p100, p17/p18) fit well with late presentations (e.g., arthritis, acrodermatitis chronica atrophicans) [39].

Regarding serum antibody detection, in case of a negative serology in serum and persisting suspicion of neuroborreliosis, antibody detection in serum should be newly performed (2-4 weeks later) to detect a potential seroconversion after a recent infection $[9,10]$. The National Institute for health and Care Excellence (NICE) guidelines also recommend to repeat the ELISA test and to perform an immunoblot test for patients with a negative ELISA test who have had symptoms for 12 weeks or more and for whom Lyme disease is still suspected $[39,40]$.

Treatment. Adult patients with definite or possible early LNB with CNS manifestations (myelitis, encephalitis, vasculitis) should be treated with IV ceftriaxone (2 $\mathrm{g}$ daily) for 14 days [21].

Late Lyme neuroborreliosis. Less than $5 \%$ have late LNB (stage III) with duration between 6 months and several years [35].

Late neurological complications are cerebral, spinal or cerebromedullary. The occurrence of late neurological manifestations after inoculation can vary in time. According to Logigian, this period varies from 6 months to 17 years, on average 5 years. Alterations in case of late LNB may be preceded by peripheral or central nervous manifestations of the early phase or on the contrary, which may be the first neurological complications of the disease $[41,42]$.

Central nervous system disorders. Chronic lymphocytic meningitis is a relatively rare manifestation of the CNS in case of late LNB, which is characterized by asymptomatic evolution, usually discovered accidentally and most often 
associated with late onset encephalitis [33]. Similar to lymphocytic meningitis, there are alterations in the CSF characterized by pleocytosis of several tens to several hundreds of elements (80-400 cells/mm3) with a modified biochemistry, increased values of CSF proteins 100-300 $\mathrm{mg} \%$ and occasionally cytoalbuminologic dissociation and normal or slightly decreased glycorrhachia may be observed. Generally, high levels of immunoglobulins in the CSF are expressed; at this stage oligoclonal bands of immunoglobulin $\mathrm{G}$ (OCBs of lgG) are present and the intrathecal synthesis of anti-Bb antibodies is also evident [33].

Progressive borrelia encephalomyelitis is the best defined late LNB with neurological complications. Most cases of progressive borrelia encephalomyelitis have been reported in Europe [42]. Both sexes are equally affected, the average age of patients is 45 years, children are less affected than adults. There are several associated clinical aspects which occur gradually and with outbreaks, and sometimes undergo spontaneous regression. These manifestations can occur as disorders of higher cortical function of varying severity: impairment of memory and judgment, disturbances of attention, changes in character, apraxia, hallucinations, and dementia. Variations in alertness, mental confusion and even coma were also reported. In some patients may appear repetitive bouts of intense psychasthenia. Some authors reported focal disturbances (hemiparesis, hemianopia, cerebellar ataxia, parkinsonism), seizures and facial nerve palsy (mainly unilateral). The clinical picture and outbreaks of progressive borrelia encephalomyelitis can simulate multiple sclerosis or stroke. Spinal cord is affected in $50 \%$ of the cases, mainly under the form of progressive spastic paraparesis or quadriparesis followed by bladder dysfunction [43-45].

Lyme encephalopathy occurs as a neuropsychiatric disorder several months or years after the time of infection with $\mathrm{Bb}$, and is classified as late stage LNB [46]. It is a cognitive disorder of moderate severity that mostly affects memory and learning, occasionally followed by psychiatric symptoms or drowsiness, which cannot be associated with neurological pathology signs or any modifications revealed by medical imaging $[47,48]$.

Peripheral nervous system disorders. Polyneuropathy and neuropathy associated with sclerotic lesions. Many patients with late LNB present a mild form of multifocal polyneuropathy which is different from early onset meningeal polyneuritis, because it does not improve spontaneously. The most common symptoms are limb paraesthesia, which are often intermittent, asymmetric, focal, affecting both the lower and upper limbs; rarely, radicular pain can also be present. A quarter of these patients presented carpal tunnel syndrome too. Distal paraesthesia generally occurs in the median nerve distribution and it is exacerbated by night-time or the use of hands; this condition is bilateral in $2 / 3$ of the cases. The presence of physical signs in case of neuropathy is rare $[20,42,43,49]$. Symptoms are accompanied by objective changes - suppressed deep tendon reflexes and/or atrophies; these symptoms are usually asymmetric and more intense in the affected skin area.

Late LNB must be considered when chronic lymphocytic meningitis or meningoencephalitis is diagnosed, especially if they are associated with peripheral cranial neuropathy or radiculoneuropathy [50].
Diagnosis. A two-tier serology in blood and CSF is recommended to demonstrate intrathecal antibody production $[35,40]$. A serological test in blood and CSF and an intrathecal antibody production (antibody index, $\mathrm{Al}$ ) are almost always positive in late neuroborreliosis, and in case of peripheral neuropathy associated with ACA. The diagnostic sensitivity of the $\mathrm{Al}$ is about $80 \%$ in patients with shorter duration (<6-8 weeks) of clinical disease and nearly $100 \%$ when the disease duration is longer. Tests can remain positive for months after a well-conducted treatment. Most guidelines therefore do not recommend these tests to assess healing $[38,49,50]$.

A lymphocytic pleocytosis in CSF, a moderately elevated level of protein, and a normal glucose level are often observed [39]. Radiological abnormalities in white matter are described in late neuroborreliosis: typical areas of inflammation with increased signal in T2 and fluid attenuated inversion recovery magnetic resonance imaging and enhancement following contrast product administration [48]. ACSF polymerase chain reaction (PCR) test is not recommended by the EFNS guidelines at this stage because of poor sensitivity and specificity $[38,50]$.

Treatment. Adult patients with definite or possible late LNB with peripheral neuropathy and ACA should be treated with oral doxycycline (200 mg daily) or IV ceftriaxone (2 g daily) for 3 weeks.

Adult patients with definite or possible late LNB with CNS manifestations (myelitis, encephalitis, vasculitis) should be treated with IV ceftriaxone ( 2 g daily) for 3 weeks [21,39].

\section{Diagnostic criteria}

Possible LNB

- typical clinical features (cranial nerve deficits, meningitis/meningoradiculitis, focal neurological deficits);

- Borrelia-specific lgG and or IgM antibodies in the serum (in very early stages of the disease, the serology may not [yet] be positive);

- CSF findings unavailable, or no lumbar puncture performed;

- exclusion of other possible causes.

Probable LNB

as in possible LNB (above) and, additionally:

- inflammatory CSF syndrome with lymphocytic pleocytosis, blood-CSF barrier disruption, and intrathecal immunoglobulin synthesis.

Definite $L N B$

as in probable LNB (above) and, additionally:

- intrathecal synthesis of Borrelia-specific antibodies (positive $\lg \mathrm{G}$ and/or IgM antibody index in CSF) or

- positive Borrelia detection by culture or by nucleic acid demonstration via PCR in CSF $[39,50]$.

\section{Conclusions}

The incidence of Lyme disease seems to be much higher than previously assumed that might be attributed to occupational exposure, leisure time activities and climate change affecting pathogen transmission. With increasing travel to endemic areas, LNB has become an international problem. Laboratory methods (namely serological tests) are essential for diagnosing LNB, but only when performed according to the guidelines of scientific medical societies, as successful 
treatment of early LNB can prevent the expensive and devastating consequences of late LNB.

Conflicts of interest: author has no conflict of interest to declare. Конфмікт інтересів: віАсутній.

Надійшла Ао реАакції / Received: 09.07.2019

Після Аоопрацювання / Revised: 01.08.2019

Прийнято Ао Аруку / Accepted: 19.08.2019

Information about author:

Poiasnyk I. M., MD, PhD, Assistant of the Department of Neurology and Neurosurgery, Ivano-Frankivsk National Medical University, Ukraine.

ORCID ID: 0000-0002-6965-8631

\section{Відомості про автора:}

Поясник І. М., канА. меА. наук, асистент каф. неврології та нейрохірургї̈, Івано-Франківський національний меАичний університет, Україна.

\section{Сведения об авторе:}

Пояснык И. М., канА. меА. наук, ассистент каф. неврологии и нейрохирургии, Ивано-Франковский национальный медицинский университет, Украина.

\section{References}

[1] Hofmann, H., Fingerle, V., Hunfeld, K. -P., Huppertz, H. -I., Krause, A., Rauer, S., Ruf, B., \& Consensus group. (2017). Cutaneous Lyme borreliosis: Guideline of the German Dermatology Society. GMS German Medical Science, 15, Article Doc14. https://doi.org/10.3205/000255

[2] Sprong, H., Hofhuis, A., Gassner, F., Takken, W., Jacobs, F., van Vliet, A. J. H., van Ballegooijen, M., van der Giessen, J., \& Taku$\mathrm{mi}, \mathrm{K}$. (2012). Circumstantial evidence for an increase in the total number and activity of borrelia-infected ixodes ricinus in the Netherlands. Parasites \& Vectors, 5, Article 294. https://doi.org/10.1186/17563305-5-294

[3] Ruyts, S. C., Ampoorter, E., Coipan, E. C., Baeten, L., Heylen, D. Sprong, H., Matthysen, E., \& Verheyen, K. (2016). Diversifying forest communities may change Lyme disease risk: extra dimension to the dilution effect in Europe. Parasitology, 143(10), 1310-1319. https:// doi.org/10.1017/s0031182016000688

[4] Hobbs, R. (2009). Woodland restoration in Scotland: Ecology, history, culture, economics, politics and change. Journal of Environmental Management, 90(9), 2857-2865. https://doi.org/10.1016/j. jenvman.2007.10.014

[5] Kauppi, P. E., Ausubel, J. H., Fang, J., Mather, A. S., Sedjo, R. A., Waggoner, P. E. (2006). Returning forests analyzed with the forest identity. Proceedings of the National Academy of Sciences, 103(46), 17574-17579. https://doi.org/10.1073/pnas.0608343103

[6] Hansford, K. M. Fonville, M. Gillingham, E. L, Coipan, E. C., Pietzsch, M. E., Krawczyk, A. I., Vaux, A. G. C., Cull, B., Sprong, H., \& Medlock, J. M. (2017). Ticks and Borrelia in urban and peri-urban green space habitats in a city in southern England. Ticks and Tick-Borne Diseases, 8(3), 353-361. https://doi.org/10.1016/j. ttbdis.2016.12.009

[7] Paul, R. E. L., Cote, M. Le Naour, E., \& Bonnet, S. I. (2016). Environmental factors influencing tick densities over seven years in a French suburban forest. Parasites \& Vectors, 9(1), Article 309. https://doi. org/10.1186/s13071-016-1591-5

[8] Vourch, G., Abrial, D., Bord, S., Jacquot, M., Masséglia, S., Poux, V., Pisanu, B., Bailly, X., \& Chapuis, J. -L. (2016). Mapping human risk of infection with Borrelia burgdorferi sensu lato, the agent of Lyme borreliosis, in a periurban forest in France. Ticks and Tick-Borne Diseases, 7(5), 644-652. https://doi.org/10.1016/j.ttbdis.2016.02.008

[9] Stanek, G., Fingerle, V., Hunfeld, K. -P., Jaulhac, B., Kaiser, R., Krause, A. Kristoferitsch, W., O'Connell, S., Ornstein, K., Strle, F., \& Gray, J. (2011). Lyme borreliosis: Clinical case definitions for diagnosis and management in Europe. Clinical Microbiology and Infection, 17(1), 69-79. https://doi.org/10.1111/j.1469-0691.2010.03175 x

[10] Borchers, A. T., Keen, C. L., Huntley, A. C., \& Gershwin, M. E. (2015). Lyme disease: A rigorous review of diagnostic criteria and treatment. Journal of Autoimmunity, 57, 82-115. https://doi.org/10.1016/j. jaut.2014.09.004
[11] Stanek, G., O'Connell, S. Cimmino, M.,Aberer, E., Kristoferitsch, W. Granström, M., Guy, E., \& Gray, J. (1996). European Union Concerted Action on Risk Assessment in Lyme Borreliosis: clinical case definitions for Lyme borreliosis. Wiener klinische Wochenschrift, 108(23), 741-747.

[12] Strle, F., Nelson, J. A., Ruzic-Sablijc, E., Cimperman, J., Maraspin, V., Lotric-Furlan, S. Cheng, Y. Picken, M. M. Trenholme, G. M. \& Picken, R. N. (1996). European Lyme Borreliosis: 231 Culture-Confirmed Cases Involving Patients with Erythema Migrans. Clinical Infectious Diseases, 23(1), 61-65. https://doi.org/10.1093/clinids/23.1.61

[13] Strle, F., Videcnik, J., Zorman, P., Cimperman, J., Lotric-Furlan, S., \& Maraspin, V. (2002). Clinical and epidemiological findings for patients with erythema migrans. Comparison of cohorts from the years 1993 and 2000. Wiener klinische Wochenschrift, 114(13-14), 493-497.

[14] Nadelman, R. B. (2015). Erythema Migrans. Infectious Disease Clinics of North America, 29(2), 211-239. https://doi.org/10.1016/.idc.2015.02.001

[15] Maraspin, V., Cimperman, J., Lotric-Furlan, S., Ruzić-Sabljić, E., Jurca, T., Picken, R. N., \& Strle, F. (2002). Solitary borrelial lymphocytoma in adult patients. Wiener klinische Wochenschrift, 114(13-14), 515-523.

[16] Asbrink, E., \& Hovmark, A. (1988). Early and Late Cutaneous Manifestations in Ixodes-borne Borreliosis (Erythema Migrans Borreliosis, Lyme Borreliosis). Annals of the New York Academy of Sciences, 539(1), 4-15. https://doi.org/10.1111/j.1749-6632.1988.tb31833.x

[17] Müllegger, R. R., \& Glatz, M. (2008). Skin Manifestations of Lyme Borreliosis. American Journal of Clinical Dermatology, 9(6), 355-368. https://doi.org/10.2165/0128071-200809060-00002

[18] Brehmer-Andersson, E., Hovmark, A., \& Asbrink, E. (1998). Acrodermatitis Chronica Atrophicans: Histopathologic Findings and Clinical Correlations in 111 Cases. Acta Dermato-Venereologica, 78(3), 207213. https://doi.org/10.1080/000155598441558

[19] Kristoferitsch, W., Sluga, E., Graf, M., Partsch, H., Neumann, R. Stanek, G., \& Budka, H. (1988). Neuropathy Associated with Acrodermatitis Chronica Atrophicans Clinical and Morphological Features. Annals of the New York Academy of Sciences, 539(1), 35-45. https:// doi.org/10.1111/j.1749-6632.1988.tb31836.x

[20] Kindstrand, E., Nilsson, B. Y., Hovmark, A., Nennesmo, I., Pirskanen, R., Solders, G., \& Asbrink, E. (2000). Polyneuropathy in late Lyme neuroborreliosis - a clinical, neurophysiological and morphological description. Acta Neurologica Scandinavica, 101(1), 47-52.

[21] Mygland, A., Ljøstad, U., Fingerle, V., Rupprecht, T., Schmutzhard, E., \& Steiner, I. (2009). EFNS guidelines on the diagnosis and management of European Lyme neuroborreliosis. European Journal of Neurology, 17(1), 8-16. https://doi.org/10.1111/j.1468-1331.2009.02862.x

[22] Steere, A. C. (2001). Lyme Disease. New England Journal of Medicine, 345(2), 115-125. https://doi.org/10.1056/nejm200107123450207

[23] Halperin, J. J. (2015). Nervous System Lyme Disease. Infectious Disease Clinics of North America, 29(2), 241-253. https://doi.org/10.1016/j. idc. 2015.02.002

[24] Ogrinc, K., Lusa, L., Lotrič-Furlan, S., Bogovič, P., Stupica, D., Cerar, T., Ružić-Sabljić, E., \& Strle, F. (2016). Course and Outcome of Early European Lyme Neuroborreliosis (Bannwarth Syndrome): Clinical and Laboratory Findings. Clinical Infectious Diseases, 63(3), 346-353. https://doi.org/10.1093/cid/ciw299

[25] Molins, C. R., Ashton, L. V., Wormser, G. P., Andre, B. G., Hess, A. M. Delorey, M. J., Pilgard, M. A., Johnson, B. J., Webb, K., Islam, M. N. Pegalajar-Jurado, A., Molla, I., Jewett, M. W., \& Belisle, J. T. (2017). Metabolic differentiation of early Lyme disease from southern tick-associated rash illness (STARI). Science Translational Medicine, 9(403), Article eaal2717. https://doi.org/10.1126/scitransImed.aal2717

[26] Ljøstad, U., Skarpaas, T., \& Mygland, A. (2007). Clinical usefulness of intrathecal antibody testing in acute Lyme neuroborreliosis. European Journal of Neurology, 14(8), 873-876. https://doi.org/10.1111/j.14681331.2007.01799.x

[27] Hammers-Berggren, S., Hansen, K., Lebech, A. -M. \& Karlsson, M. (1993). Borrelia burgdorferi-specific intrathecal antibody production in neuroborreliosis. Neurology, 43(1 Pt. 1), 169-175. https:// doi.org/10.1212/wnl.43.1 part 1.169

[28] O'Connell, S. (2010). Lyme borreliosis: current issues in diagnosis and management. Current Opinion in Infectious Diseases, 23(3), 231-235. htps://doi.org/10.1097/qco.0b013e32833890e2

[29] Skogman, B. H. Croner, S. Nordwall, M.. Eknefelt, M., Ernerudh, J., \& Forsberg, P. (2008). Lyme Neuroborreliosis in Children. The Pediatric Infectious Disease Journal, 27(12), 1089-1094. https://doi.org/10.1097/ inf.0b013e $31817 f d 423$

[30] Skeie, G. O., Eldøen, G., Skeie, B. S., Midgard, R., Kristoffersen, E. K., \& Bindoff, L. A. (2007). Opsoclonus myoclonus syndrome in two cases with neuroborreliosis. European Journal of Neurology, 14(12), Article e1-e2. https://doi.org/10.1111/j.1468-1331.2007.01959.x

[31] Țilea, B., Bălașa, R., Fodor, A., \& Țilea, I. (2016). Diagnosis and Treatment Algorythm in Lyme Neuroborreliosis. Acta Medica Marisiensis, 62(1), 121-127. https://doi.org/10.1515/amma-2015-0125 
[32] Wormser, G. P., Dattwyler, R. J., Shapiro, E. D., Halperin, J. J. Steere, A. C., Klempner, M. S., Krause, P. J., Bakken, J. S., Strle, F., Stanek, G., Bockenstedt, L., Fish, D., Dumler, J. S., \& Nadelman, R. B. (2006). The Clinical Assessment, Treatment, and Prevention of Lyme Disease, Human Granulocytic Anaplasmosis, and Babesiosis: Clinical Practice Guidelines by the Infectious Diseases Society of America. Clinical Infectious Diseases, 43(9), 1089-1134. https://doi. org/10.1086/508667

[33] Halperin, J. J. (1995). Neuroborreliosis. The American Journal of Medicine, 98(4 Suppl. 1), 52S-59S. https://doi.org/10.1016/s00029343(99)80044-8

[34] Sprong, H., Azagi, T., Hoornstra, D., Nijhof, A. M., Knorr, S., Baarsma, M. E., \& Hovius, J. W. (2018). Control of Lyme borreliosis and other Ixodes ricinus-borne diseases. Parasites \& Vectors, 11(1), Article 145 https://doi.org/10.1186/s13071-018-2744-5

[35] Ljøstad, U., Skogvoll, E., Eikeland, R., Midgard, R., Skarpaas, T. Berg, A., \& Mygland, A. (2008). Oral doxycycline versus intravenous ceftriaxone for European Lyme neuroborreliosis: a multicentre, non-inferiority, double-blind, randomised trial. The Lancet Neurology, 7(8), 690-695. https://doi.org/10.1016/s1474-4422(08)70119-4

[36] Kruger, H., Reuss, K., Pulz, M., Rohrbach, E., Pflughaupt, K. -W., Martin, R., \& Mertens, H. G. (1989). Meningoradiculitis and encephalomyelitis due to Borrelia burgdorferi: a follow-up study of 72 patients over 27 years. Journal of Neurology, 236(6), 322-328. https://doi. org/10.1007/bf00314373

[37] Dersch, R., Toews, I., Sommer, H., Rauer, S., \& Meerpohl, J. J. (2015). Methodological quality of guidelines for management of Lyme neuroborreliosis. BMC Neurology, 15, Article 242. https://doi.org/10.1186/ s12883-015-0501-3

[38] Dessau, R. B., van Dam, A. P., Fingerle, V., Gray, J., Hovius, J. W., Hunfeld, K. -P., Jaulhac, B., Kahl, O., Kristoferitsch, W., Lindgren, P. -E., Markowicz, M., Mavin, S., Ornstein, K., Rupprecht, T., Stanek, G., \& Strle, F. (2018). To test or not to test? Laboratory support for the diagnosis of Lyme borreliosis: a position paper of ESGBOR, the ESCMID study group for Lyme borreliosis. Clinical Microbiology and Infection, 24(2), 118-124. https://doi.org/10.1016/j.cmi.2017.08.025

[39] Taba, P., Schmutzhard, E., Forsberg, P., Lutsar, I., Ljøstad, U., Mygland, A., Levchenko, I., Strle, F., \& Steiner, I. (2017). EAN consensus review on prevention, diagnosis and management of tick-borne encephalitis. European Journal of Neurology, 24(10), 1214-e61. https:// doi.org/10.1111/ene.13356

[40] Oschmann, P., Dorndorf, W., Hornig, C., Schäfer, C., Wellensiek, H. J., \& Pflughaupt, K. W. (1998). Stages and syndromes of neuroborreliosis. Journal of Neurology, 245(5), 262-272. https://doi.org/10.1007/s004150050216

[41] Mygland, A., Skarpaas, T., \& Ljøstad, U. (2006). Chronic polyneuropathy and Lyme disease. European Journal of Neurology, 13(11), 1213-1215. https://doi.org/10.1111/j.1468-1331.2006.01395.x

[42] Topakian, R., Stieglbauer, K., Nussbaumer, K., \& Aichner, F. T. (2008). Cerebral Vasculitis and Stroke in Lyme Neuroborreliosis. Cerebrovas cular Diseases, 26(5), 455-461. https://doi.org/10.1159/000155982

[43] Charles, V., Duprez, T. P., Kabamba, B., Ivanoiu, A., \& Sindic, C. J. M. (2007). Poliomyelitis-like syndrome with matching magnetic resonance features in a case of Lyme neuroborreliosis. Journal of Neurology, Neurosurgery \& Psychiatry, 78(10), 1160-1161. https://doi.org/10.1136/ jnnp.2007.121103

[44] Beuchat, I., Dunet, V., Meylan, P., \& Du Pasquier, R. (2018). Late Lyme neuroborreliosis with chronic encephalomyelitis. Neurology, 91(13), 627-628. https://doi.org/10.1212/wnl.0000000000006252

[45] Schwenkenbecher, P., Pul, R., Wurster, U., Conzen, J., Pars, K., Hartmann, H., Sühs, K.-W., Sedlacek, L., Stangel, M., Trebst, C., \& Skripuletz, T. (2017). Common and uncommon neurological manifestations of neuroborreliosis leading to hospitalization. BMC Infectious Diseases, 17(1), Article 90. https://doi.org/10.1186/s12879-016-2112-z

[46] Kristoferitsch, W., Aboulenein-Djamshidian, F., Jecel, J., Rauschka, H. Rainer, M., Stanek, G., \& Fischer, P. (2018). Secondary dementia due to Lyme neuroborreliosis. Wiener Klinische Wochenschrift, 130(15-16), 468-478. https://doi.org/10.1007/s00508-018-1361-9

[47] Miklossy, J. (2012). Chronic or Late Lyme Neuroborreliosis: Analysis of Evidence Compared to Chronic or Late Neurosyphilis. The Open Neurology Journal, 6(Suppl. 1), 146-157. https://doi. org/10.2174/1874205x01206010146

[48] Lindland, E. S., Solheim, A. M., Andreassen, S., Quist-Paulsen, E., Eikeland, R., Ljøstad, U., Mygland, Å., Elsais, A., Nygaard, G. O., Lorentzen, A. R., Harbo, H. F., \& Beyer, M. K. (2018). Imaging in Lyme neuroborreliosis. Insights into Imaging, 9(5), 833-844. https:// doi.org/10.1007/s13244-018-0646-x

[49] Halperin, J., Luft, B. J., Volkman, D. J., \& Dattwyler, R. J. (1990). Lyme neuroborreliosis: Peripheral nervous system manifestations. Brain, 113(4), 1207-1221. https://doi.org/10.1093/brain/113.4.1207

[50] Rauer, S., Kastenbauer, S., Fingerle, V., Hunfeld, K. -P., Huppertz, H. -I., \& Dersch, R. (2018). Lyme neuroborreliosis. Deutsches Aerzteblatt Online, 115(45), 751-756. https://doi.org/10.3238/arztebl.2018.0751 